\title{
MONITORING OF ACTIVE FIRE EVENTS DUE TO PADDY RESIDUE BURNING IN INDO-GANGETIC PLAINS USING THERMAL REMOTE SENSING
}

\author{
Aakash Chhabra ${ }^{1, *}$, Vinay Kumar Sehgal ${ }^{1, *}$, Rajkumar Dhakar $^{1}$, Niveta Jain ${ }^{2}$, Rakeshwar Verma ${ }^{1}$ \\ ${ }^{1}$ Division of Agricultural Physics, ${ }^{2}$ Centre for Environment Science and Climate Resilient Agriculture \\ ICAR - Indian Agricultural Research Institute (IARI), New Delhi, India - 110012 \\ (*aakash.chhabra7489@gmail.com,*vk.sehgal@icar.gov.in)
}

KEY WORDS: Rice, VIIRS, MODIS, AVHRR, Fire, residue burning

\begin{abstract}
:
In India, stubble burning is frequently practiced in the dominant rice-growing states of the Indo-Gangetic Plains, primarily in Punjab, Haryana and Uttar Pradesh. We attempted monitoring and mapping of the active fire events in real time for all the 3 states by acquiring thermal datasets from 3 different sensors i.e. Visible Infrared Imaging Radiometer Suite (VIIRS) at 375m aboard SumoNPP, Moderate-Resolution Imaging Spectro-Radiometer (MODIS) at $1000 \mathrm{~m}$ aboard Terra \& Aqua, and Advanced Very High Resolution Radiometer (AVHRR) at 1,100m aboard NOAA 18/19 \& MetOp 1/2, made available by IARI Satellite Ground Station during Kharif crop harvest season (October-November) 2018. The standard algorithm of detection of the temperature of a pixel at (4.0 $\mu \mathrm{m}$ and/or 10 to $12 \mu \mathrm{m}$ ) and its difference from the temperature of surrounding pixels was employed for day and night passes. Analysis of active fire locations detected from VIIRS, MODIS and AVHRR between $01^{\text {st }}$ October and $30^{\text {th }}$ November 2018 suggests continuing practice of stubble burning with a total of 75563 burning events distributed as 59695, 9232 and 6636 in Punjab, Haryana and Uttar Pradesh, respectively. District-wise monitoring showed a significant upsurge of fire events during the study period in the south-western and eastern districts of Punjab. Intense fire was witnessed in northern districts of Haryana and western districts of Uttar Pradesh. Comparative analysis shows that the burning events in the current year up till $30^{\text {th }}$ November 2018 are $85 \%$ of the events detected in 2017 and about $59.10 \%$ of the events detected in 2016. It implies that the burning of rice stubble in the current year has reduced significantly over the past years due to various scheme implemented by the State and Central government.
\end{abstract}

\section{INTRODUCTION}

\section{General Background}

Paddy residue burning is a common practice in the rice producing states, namely, Punjab, Haryana and Uttar Pradesh, located in the Indo-Gangetic Plain (IGP) (Badarinath, 2006), (Gupta, 2012), (Badarinath, 2009) and (Sharma, 2010). It is primarily exercised to clear the left-over straw during the harvest of rice at the end of Kharif season and prepare the field for the next sowing cycle. The dominating cropping system in these states is rice-wheat rotation which accounts more than 10 million hectare (Ladha, 2000) and (Ladha, 2003). Assortment of different rice varieties (coarser grain rice over fine grain) and the mechanization of the conventional harvesting methods by the farmers in these regions has resulted in producing large amount of crop biomass in the form of straw (Gupta, 2012a) and (Gupta, 2012b). According to Indian Agricultural Research Institute (IARI), cereal crop nearly generates a total of about $352 \mathrm{Mt}$ of residue, of which rice and wheat contribute to nearly $34 \%$ and $22 \%$ respectively. It may be economical for the farmer to burn the paddy residue for land clearance, however, this results in adding huge amounts of aerosols, particulate matter and GHG emissions (Badarinath, 2009), (Vadrevu, 2012) and (Vadrevu, 2013) (Figure 1). These emissions have the tendency to change the atmospheric state and chemistry, thus resulting in climate change (Crutzen, 1990) and (Andreae, 2001).

In recent years, there has been promising development in monitoring biomass burning in an agricultural landscape as it is a significant agent for altering the climate at regional and global scale. Satellite-based observations from coarse and medium resolution sensors onboard the polar orbiting satellites have met the demand by recent advancements and increase in the number of sensors, Advanced Very High Resolution Radiometer (AVHRR), the Moderate Resolution Imaging Spectroradiometer (MODIS), the Along-Track Scanning Radiometer (ATSR) and Advanced Along-Track Scanning Radiometer (AATSR), the Visible and Infrared Scanner (VIRS), the Geostationary Operational Environmental Satellite (GOES) Imager, the Operational Linescan System (OLS), and the Spinning Enhanced Visible and Infrared Imager (SEVIRI) (Arino , 1999), Elvidge, 1996); (Giglio, 2003), (Justice, 1996), (Justice, 2002), and (Roberts, 2007). Along with increasing satellite remote sensing sensors and its applications, monitoring the biomass burning on a large scale through satellite data has become a definitive manner in order to monitor and mitigate the illicit burning that directly effects the air health quality.

The Consortium for Research on Agro-Ecosystem Monitoring and Modelling from Space (CREAMS) at Indian Agricultural Research Institute (IARI), New Delhi, regularly monitors the active fire events due to stubble burning at regional scales (Figure 2). In this study, an attempt was made to analyze the fire locations, fire frequency and fire intensity of active fire events during the paddy-residue burning in the North-Western states of India using satellite remote sensing and geospatial technologies. This paper aims at monitoring the spatialtemporal variability of the burning events in the IGP during the period $1^{\text {st }}$ October 2018 to $30^{\text {th }}$ November 2018. Descriptive statistics discusses the occurrence of the events district, date and fire-intensity wise and also draws a comparison with stubble burning statistics for 2017 and 2016.

* Corresponding author 


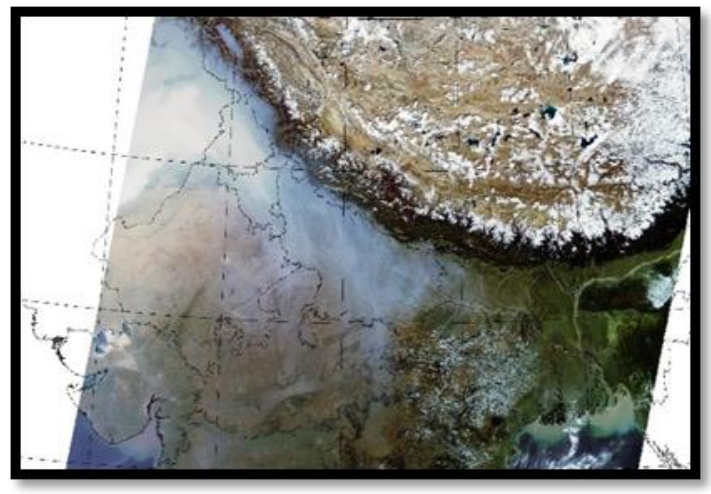

Figure 1. Satellite imagery of Northern India by TERRA MODIS taken during the day on $03^{\text {rd }}$ November 2017 showing high density of plumes over the Indo-Gangetic Plain (IGP). (Source: IARI - Satellite Ground Station)

\section{MATERIALS AND METHODS}

\subsection{Study region}

This study focused on the pre-dominating rice residue burning areas of north-west (NW) India viz. Punjab, Haryana and Uttar Pradesh for the detection of active fire points (Figure 3). These states are situated in Indo-Gangetic Plain (IGP) of India which covers about $20 \%$ geographic area and contributes to nearly $42 \%$ of the total food grain production in India, making it one of the most agriculturally productive regions in the world (Vadrevu, 2011). In these regions, farmers largely practice the rice-wheat cropping system. Rice is usually grown in the Kharif season (sown in July-August and harvested in OctoberNovember) and wheat in the Rabi season (sown in NovemberDecember and harvested in April-May).

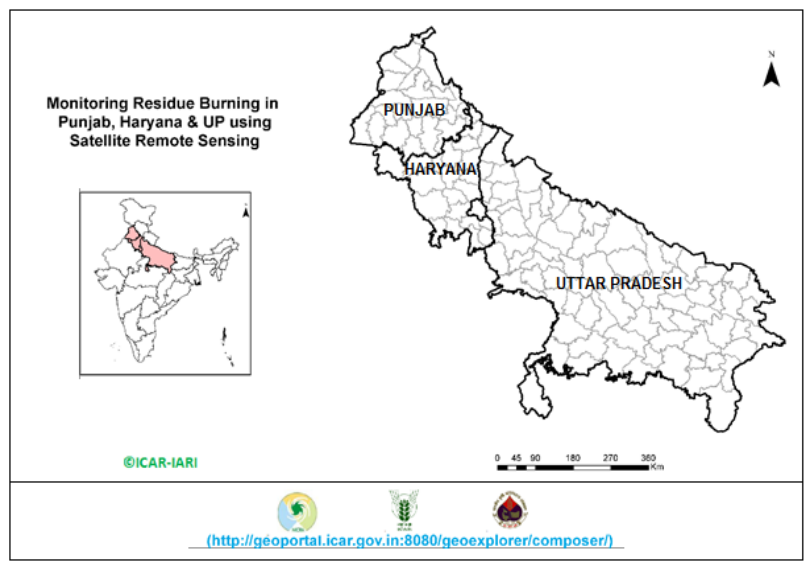

Figure 3. Study area location map depicting Punjab, Haryana and UP states in India

\subsection{Dataset used}

In this study, the real-time detection of the active fire events for both, day and night, were accomplished by acquiring the daily thermal datasets from the seven different polar-orbiting satellites during the monitoring period, $01^{\text {st }}$ October, 2018 to $30^{\text {th }}$ November, 2018. Table 1 summarizes the details of satellite with their respective sensors, resolution etc. The

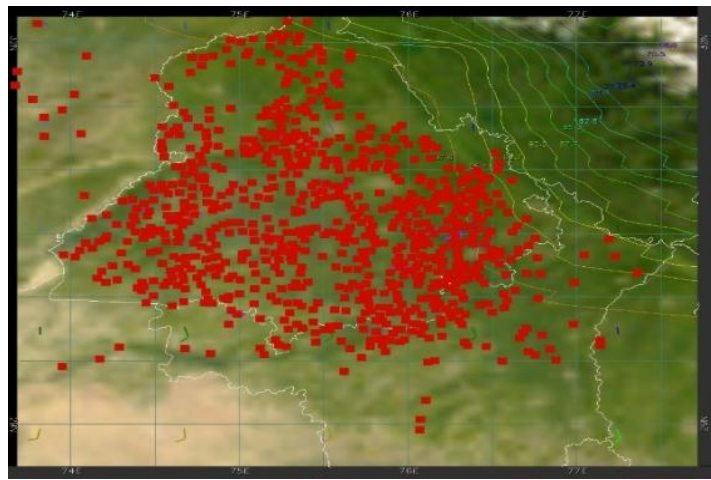

Figure 2. Active fire events detected in Punjab on $26^{\text {th }}$ October 2016 using AQUA-MODIS (1000m). (Source: CREAMS, IARI)

images from the satellites were received at IARI Satellite Ground Station. In addition, the satellite thermal datasets for these regions for the monitoring months (Oct-Nov) was also acquired for 2016 and 2017. Active fire products derived from daily images from MODIS, VIIRS and AVHRR/3 conveyed, for each pixel, critical information on, acquisition date/day of fire, location of the fire (latitude/longitude), confidence of the detected fire, and fire intensity quantified in watt per sq. meter $\left(\mathrm{W} / \mathrm{m}^{2}\right)$ (Giglio, 2003) and (Schrodeger, 2014).

\subsection{Algorithm for detecting active fire events}

The active fire detection algorithm was allocated into two modules; day and nighttime. Both the modules were driven by fire sensitive Shortwave-Infrared (SWIR), Middle-waveInfrared (MWIR) and Longwave-Infrared (LWIR) spectral channels, exploiting the emissivity component of the fires.

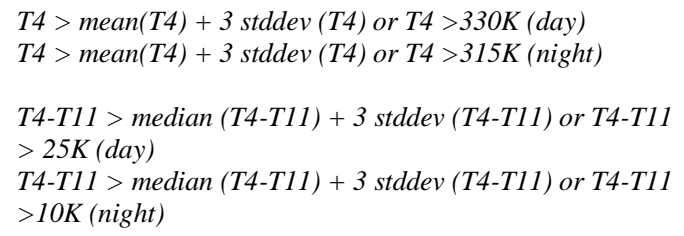

Where, stddev $=$ Standard Deviation in T4 $(4 \mu \mathrm{m})$

Fire detection for both day and night was successful for MODIS and VIIRS sensors as they employ a highly sensitive $3.9 \mu \mathrm{m}$ channel that has a strong thermal response to even a smaller portion of fire in a pixel. Moderate Resolution Imaging Spectroradiometer (MODIS) is a 36-channel imager aboard TERRA with equatorial crossing (descending at 10:30am) and AQUA with equatorial crossing (ascending at 1:30 pm). MODIS has 2 channels designated at $250 \mathrm{~m}, 5$ channels at $500 \mathrm{~m}$ and 29 channels at $1000 \mathrm{~m}$, spatial resolution, and a viewing swath of $2330 \mathrm{~km}$. MODIS sensor derives brightness temperatures from the MODIS $4 \mu \mathrm{m}$ and $11 \mu \mathrm{m}$ channels, denoted by $\mathrm{T} 4$ and T11, respectively. The MODIS instrument has two $4 \mu \mathrm{m}$ channels, numbered 21 and 22, both of which are used by the fire-detection algorithm. Channel 21 and 22 saturate at nearly $500 \mathrm{~K}$ and $331 \mathrm{~K}$, respectively. Since Channel (22) is less noisy and has a relatively smaller quantization error, T4 is derived from this particular channel. Whenever, channel 22 saturates, T4 is then derive from higher 
saturation channel. T11 is computed from the $11 \mu \mathrm{m}$ channel (channel 31), which saturates at approximately $400 \mathrm{~K}$. Using the threshold values for both day and night, the anomalous temperatures are detected with background characterization and thus the pixel is tagged as fire. For masking cloud the $12 \mu \mathrm{m}$ is used, the brightness temperatures for which are denoted and distinguished by T12 (Kaufman, 1998). Visible Infrared imager Radiometer Suite (VIIRS) instrument on S-NPP satellite is a scanning imaging radiometer with a viewing swath of $3000 \mathrm{~km}$. VIIRS has 22 channels- 9 in the visible/near-IR (VIS/NIR) range, 8 channels in the shortwave/mid-wave IR range (SW/MWIR), 4 in the longwave-IR (LWIR) range, and 1 day/night channel. It extends and improves on capabilities of the AVHRR and MODIS sensors to measure land surface temperatures, fires and albedo. The fire detection algorithm of VIIRS at $375 \mathrm{~m}$ builds on the MODIS and AVHRR fire detection algorithm (Csiszar, 2014) and is also capable of detecting smaller and cooler fires (Schroeder, 2014). The active fire algorithm of VIIRS instrument is based on $375 \mathrm{~m}$ (I-bands) and $750 \mathrm{~m}$ (M-bands). The related attributes for each fire within the study area were then converted to point shape files and were subsequently masked for agriculture pixels using a spatial layer from land-sue/land-cover dataset for further analysis.

\begin{tabular}{|c|c|c|c|c|c|c|}
\hline $\begin{array}{c}\text { Administering } \\
\text { Agency }\end{array}$ & Satellite & Sensor & $\begin{array}{l}\text { Wavelength } \\
(\mu \mathrm{m})\end{array}$ & $\begin{array}{c}\text { Spatial } \\
\text { Res. (m) }\end{array}$ & $\begin{array}{c}\text { Passes } \\
(\mathrm{D} / \mathrm{N})\end{array}$ & Telemetry \\
\hline NASA (USA) & S-NPP & VIIRS & $\begin{array}{c}3.660-3.840 \\
10.263-11.263 \\
\end{array}$ & 375 & Both & NPPDB \\
\hline NASA (USA) & AQUA & MODIS & \multirow{2}{*}{$\begin{array}{c}\text { Channel } 21 \\
(3.929-3.989) \\
\text { Channel } 22 \\
(3.929-3.989) \\
\text { Channel } 31 \\
(10.780-1.280) \\
\end{array}$} & 1000 & Both & AQUADB \\
\hline NASA (USA) & TERRA & MODIS & & 1000 & Both & TERADB \\
\hline NOAA (USA) & NOAA-18 & AVHRR/3 & \multirow[b]{2}{*}{$\begin{array}{c}\text { Channel 3B (3.55 } \\
-3.93) \\
\text { Channel } 4 \text { (10.30 } \\
-11.30)\end{array}$} & 1100 & Night & HRPT \\
\hline NOAA (USA) & NOAA-19 & AVHRR/3 & & 1100 & Night & HRPT \\
\hline EUMETSAT (EU) & MetOp-1 & AVHRR/3 & \multirow[b]{2}{*}{$\begin{array}{c}\text { Channel 3B (3.55 } \\
-3.93) \\
\text { Channel } 4(10.30 \\
-11.30)\end{array}$} & 1100 & Night & AHRPT \\
\hline EUMETSAT (EU) & MetOp-2 & AVHRR/3 & & 1100 & Night & AHRPT \\
\hline
\end{tabular}

Table 1: Summary of satellite thermal data received at IARI Satellite Ground Station for fire detection.

\section{RESULTS}

The data on daily residue burning events of three states was analyzed from three different sensors in following ways. As district layer is the most commonly used administrative unit in India, the results are presented at this scale for meaningful interpretation of data.

\subsection{MODIS versus VIIRS Fire Count}

The bar graphs in Figure 4 illustrates the total number of burning events (Day and Night) detected by VIIRS and
MODIS sensors across all three states, namely, Punjab, Haryana and Uttar Pradesh during 2016, 2017 and 2018. It can be clearly seen that VIIRS was much more capable of detecting small and large active fires at $375 \mathrm{~m}$ than the MODIS at $1000 \mathrm{~m}$ for all the three states during 2016, 2017 and 2018. For Punjab (Figure $4 a$ ) the VIIRS fire counts, averaged across three years, were 6.25 times higher than the averaged fire count of MODIS on TERRA and AQUA combined. Whereas, for Haryana (Figure 4b), the VIIRS fire counts, averaged across three years, were nearly 6.0 times higher than the averaged fire count of MODIS on TERRA and AQUA combined. For the state, Uttar Pradesh (Figure 4c), VIIRS fire counts, averaged across three years, is 6.95 times higher than the averaged fire count of MODIS on TERRA and AQUA combined. 


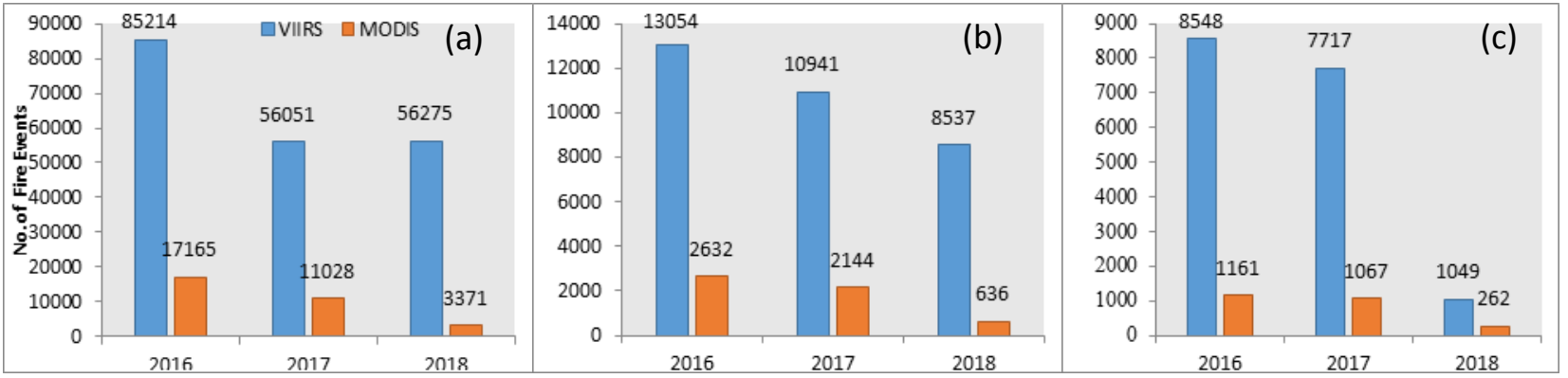

Figure 4. Comparison of number of active fire locations detected by MODIS and VIIRS sensors during 2018, 2017 and 2016 for (a) Punjab, (b) Haryana, and (c) UP.

\subsection{Temporal distribution of active fire events}

Figure 5 shows the daily occurences of the burning events in all the three states during the monitoring period $01^{\text {st }}$ October to $30^{\text {th }}$ November 2018. Maximum burning for all the three states was observed during $23^{\text {rd }}$ October to $15^{\text {th }}$ November 2018 implying harvest of rice during this period. A sudden decrease depicted in the fire count for Punjab and Haryana on $3^{\text {rd }} \& 4^{\text {th }}$ November was due to cloud cover, suggesting, the satellites couldn't detect the fire events, a limitation of satellite remote sensing.

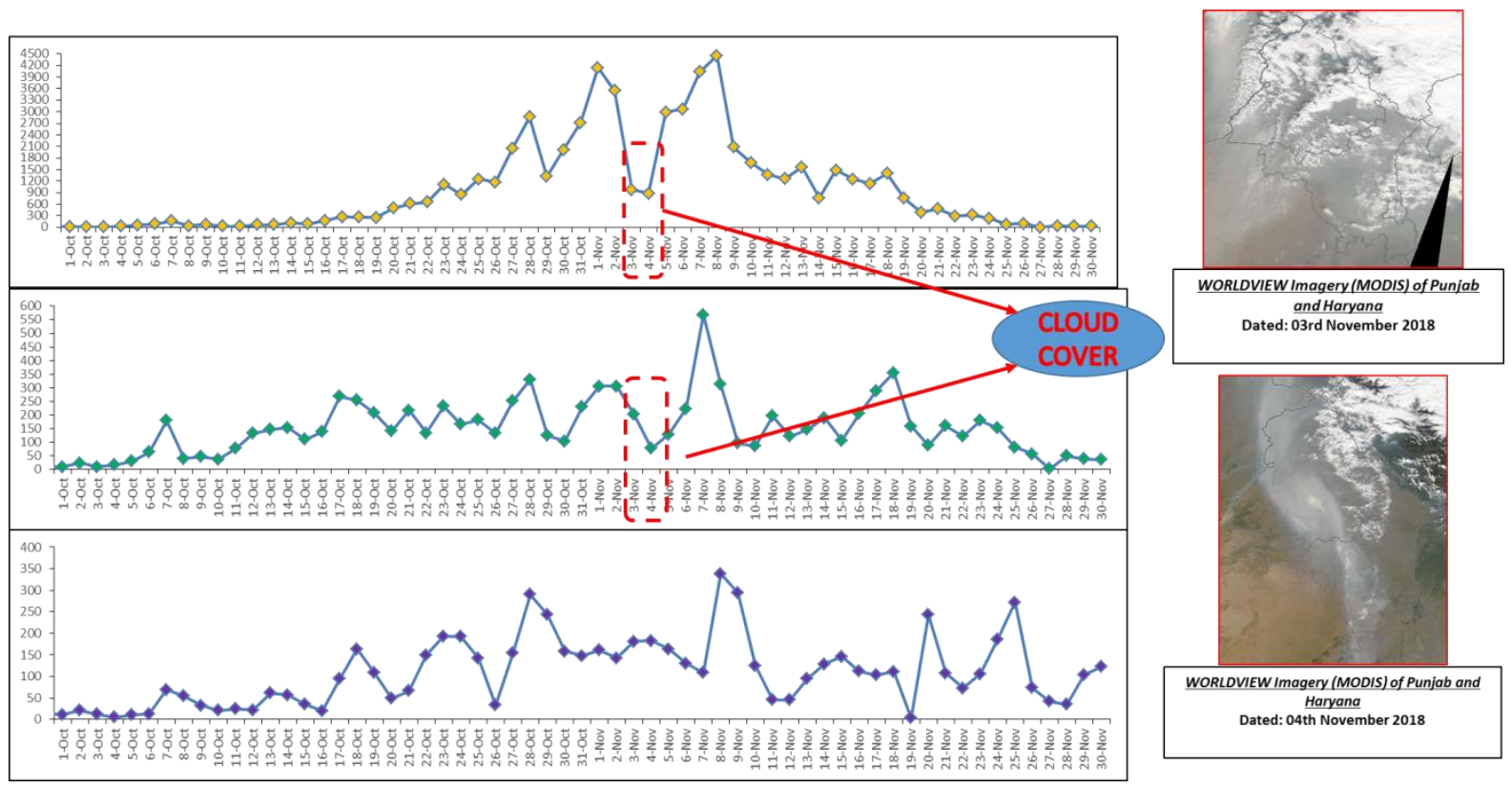

Figure 5. Temporal distribution of active fire events during the monitoring period in 2018. (Yellow: Punjab; Green: Haryana; Purple: Uttar Pradesh)

\subsection{Spatio-temporal distribution of active fire events based on fire intensity}

Figure 6 shows the spatio-temporal distribution of active fire locations due to stubble burning across all the three states as captured by MODIS, VIIRS and AVHRR/3 sensors during the period $01^{\text {st }}$ October to $30^{\text {th }}$ November 2018. The active fire points were classified based on their fire intensity measured in Watts per sq. meter $\left(\mathrm{W} / \mathrm{m}^{2}\right)$.
Figure 6 shows that in Punjab higher intensity fire events occurred in the Central, South-Western, and South-Eastern districts. Whereas, in Haryana the intense burning was focused in Northern districts bordering Punjab. In Uttar Pradesh, high intensity fires were scattered. The measurement of fire intensity will assist in estimating GHG emissions. 
The International Archives of the Photogrammetry, Remote Sensing and Spatial Information Sciences, Volume XLII-3/W6, 2019 ISPRS-GEOGLAM-ISRS Joint Int. Workshop on "Earth Observations for Agricultural Monitoring", 18-20 February 2019, New Delhi, India
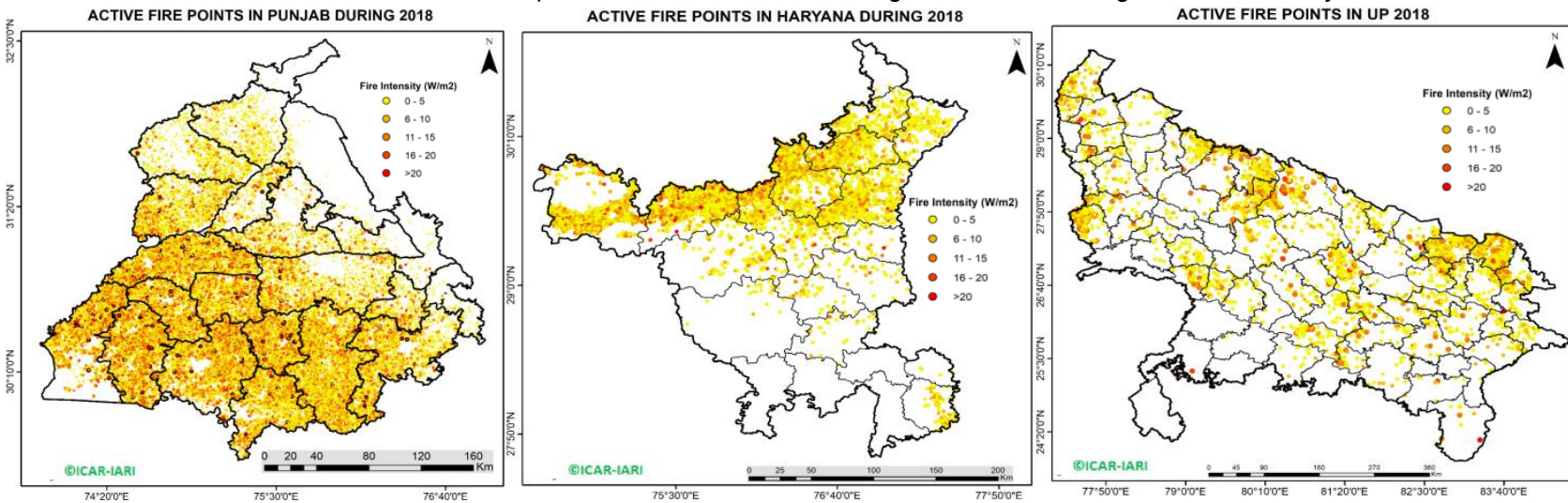

Figure 6. Spatial distribution of active fire locations (VIIRS, MODIS and AVHRR based) in (a) Punjab (b) Haryana and (c) Uttar Pradesh during $01^{\text {st }}$ October to $30^{\text {th }}$ November 2018.

\subsection{Monitoring of residue burning events at district scale}

The daily residue burning events in a district were summed over monitoring period ( $1^{\text {st }}$ October to $30^{\text {th }}$ November) for 2018 (Figure 7 \& 8). Sangrur district of Punjab had maximum residue burning events. About 2700 average burning events per district were observed in Punjab, while the figure was 440 and 90 in the Haryana and UP, respectively. Twelve districts, Barnala, Bhatinda, Faridkot, Fazilka, Firozpur, Ludhiana, Mansa,
Moga, Muktsar, Patiala, Sangrur and Tarn Taran recorded higher residue burning events than the average burning events per district. In Haryana, six districts viz., Fatehabad, Sirsa, Kaithal, Karnal, Jind and Kurushetra had higher burning events than its state average. These districts contributed to about $87 \%$ of total burning events in the state. Likewise, six district viz., Mathura, Mahrajganj, Siddharthnagar, Sahajanpur, Pilibhit and Kheri contributed about 56 percent of total burning in U.P.

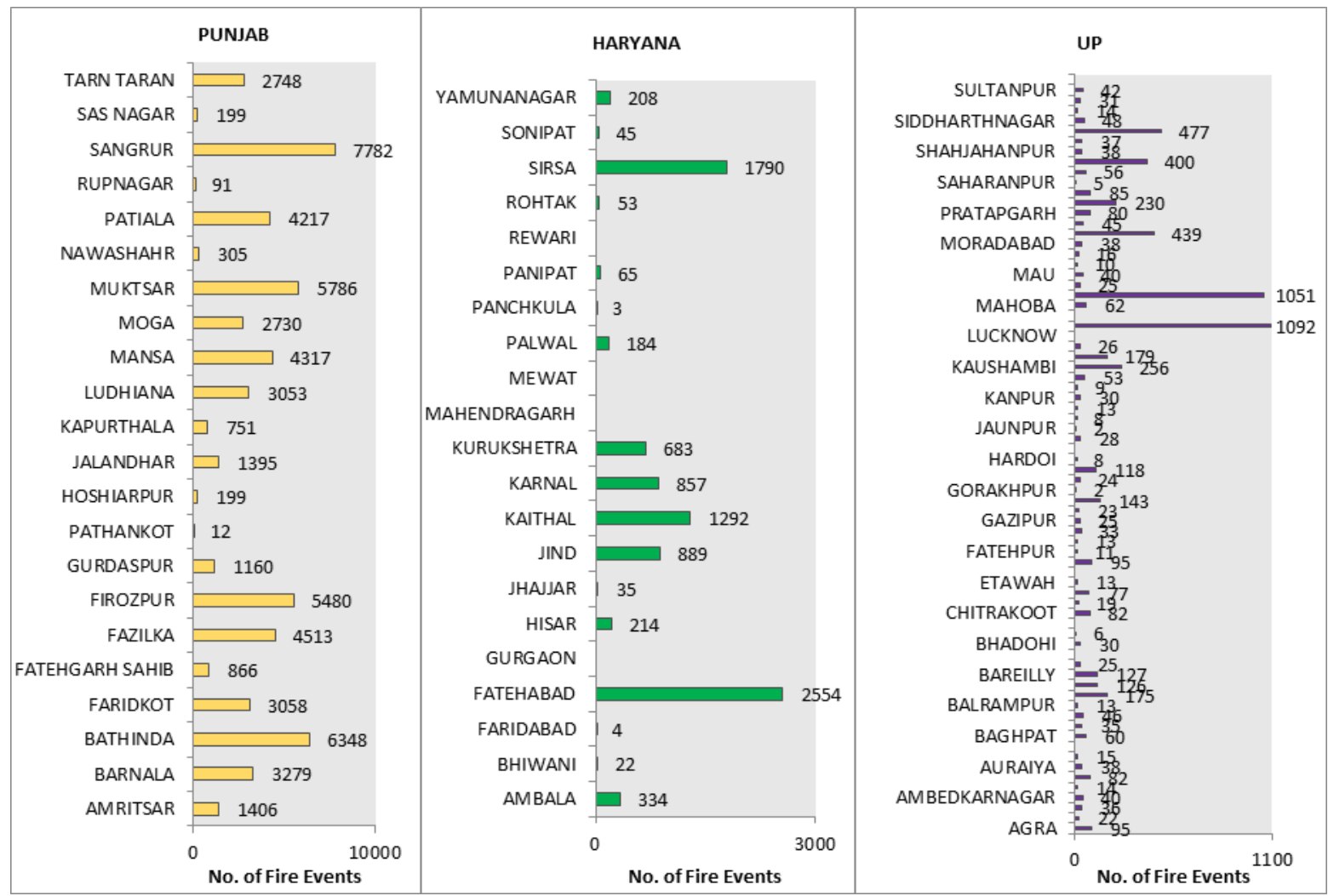

Figure 7. District-wise cumulative number of residue burning events over the period of $1^{\text {st }}$ October to $30^{\text {th }}$ November 2018. (Yellow: Punjab; Green: Haryana; Purple: Uttar Pradesh) 

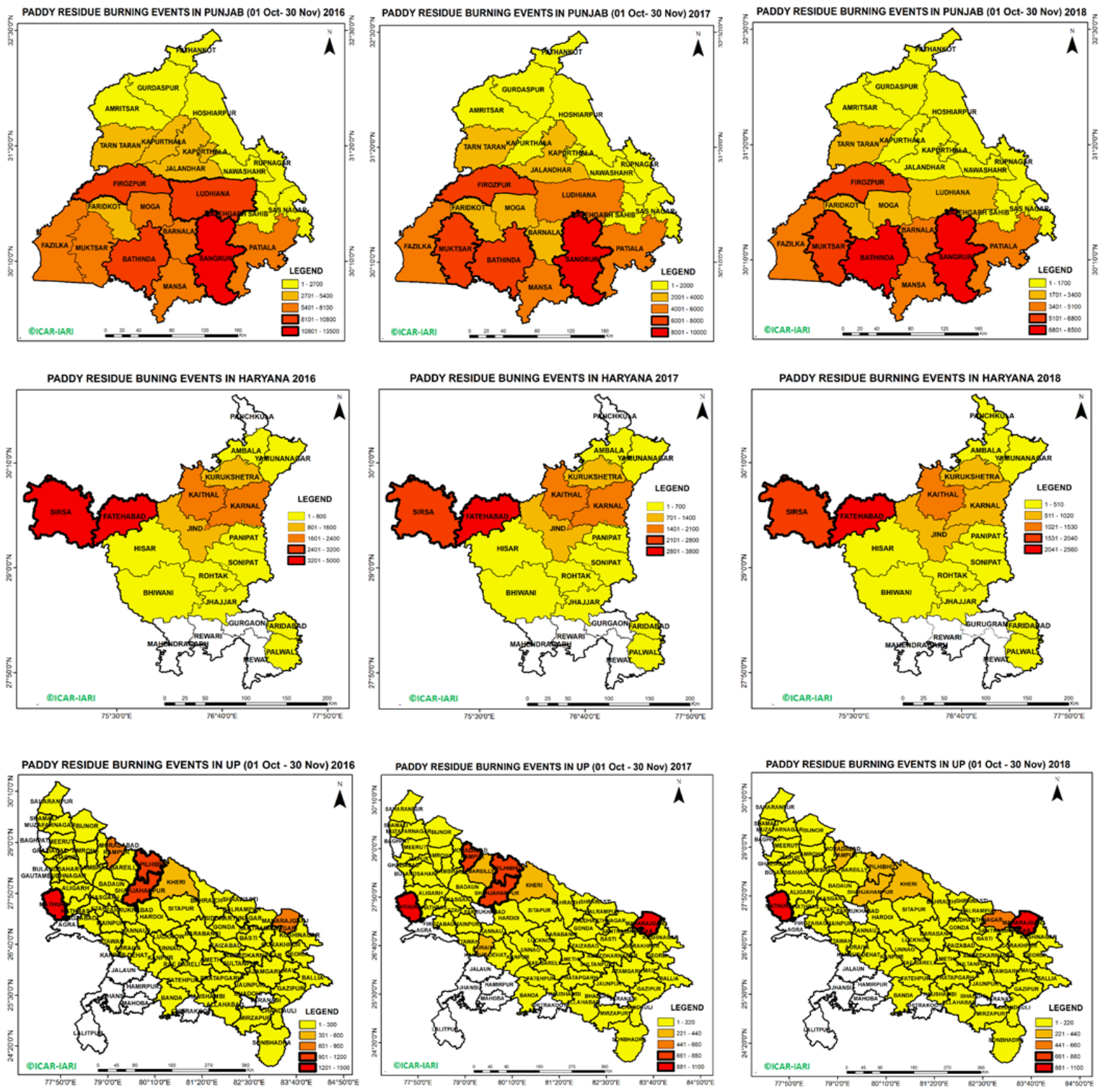

Figure 8. Map depicting the district-wise fire count in Punjab, Haryana and Uttar Pradesh for 2016, 2017 and 2018

\subsection{Annual comparison of daily cumulative burning events}

Daily cumulative residue burning events for the three years were plotted as line graph (Figure 9) to infer the rate of burning events during the study period. The results showed that rate of burning events in 2016 were high as compared to 2017 and 2018 , over the whole study period. Rate of burning events was slower in initial period during 2018 compared to 2017, but it compensated the initial slower pace after $1^{\text {st }}$ November up to $20^{\text {th }}$ November, even though overall burning events were higher during 2017 than 2018.
Haryana experienced significantly slower pace of burning events throughout the study period during 2018 as compared to that of 2017 and 2016. The rate of burning events in the month of October was almost similar during 2016 and 2017, but 2016 gained more pace in the month of November resulted into overall higher burning events. Uttar Pradesh also experienced significantly slower pace of burning events throughout the study period during 2018 as compared to 2017 and 2016. The rate of active fire events during $1^{\text {st }}$ October to $25^{\text {th }}$ October was almost comparable during year 2016 and 2017, but 2016 gained rapidity in the later period resulting into overall higher active fire events during the study period. 


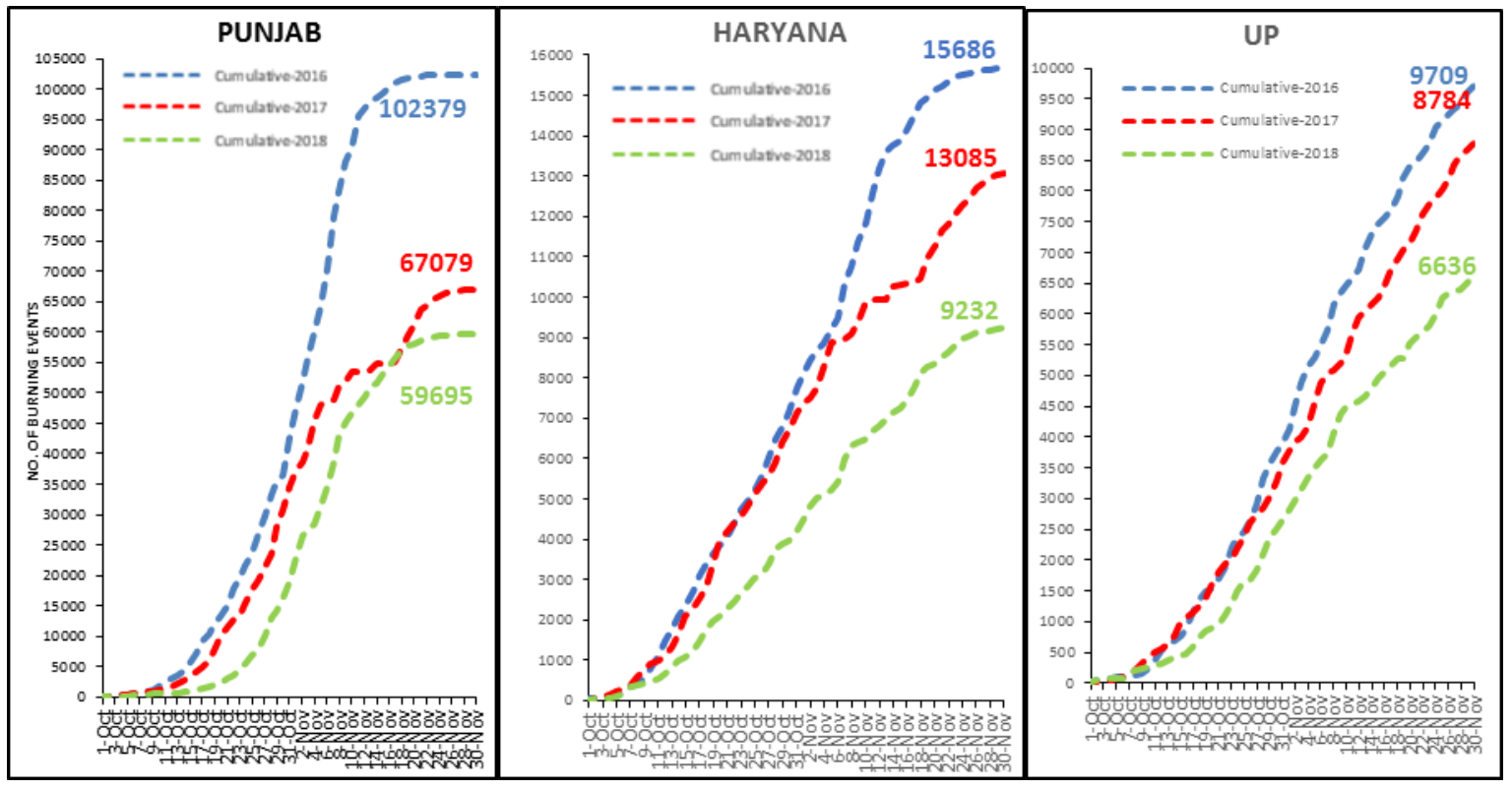

Figure 9. Comparison of burning events of 2018 with events in 2016 and 2017.

\subsection{District-wise annual comparison of residue burning events}

The residue burning events of 2018 were compared with that of previous two years viz., 2016 and 2017. A total of 75563 (59695 (79\%), 9232 (12\%) and 6636 (9\%) in Punjab, Haryana and UP, respectively) burning events were detected in the three states between $01^{\text {st }}$ October and $30^{\text {th }}$ November 2018. Overall, about $15 \%$ and $41 \%$ reduction in number of burning events were observed in current year (2018) as compared to that in 2017 and 2016, respectively. The reduction in number of burning events in current year was $11 \%$ in Punjab, $29.44 \%$ in Haryana and $24.60 \%$ in UP as compared to events in 2017.

In Punjab (Figure 10), of the total of 22 districts, 13 (Sangrur, Ludhiana, Bathinda, Firozpur, Muktsar, Patiala, Moga, Barnala, Mansa, Fazilka, Jalandhar, Faridkot and Tarn Taran) consistently depicted aggressive burning events in 2018, 2017 and 2016. Similarly, in Haryana (Figure 10), of the total 21 districts, 5 (Fatehabad, Sirsa, Kaithal, Karnal, Kurukshetra and Jind) showed higher burning in these three years. In UP (Figure 10), of the 75 districts, the burning was consistently high in 10 (Mathura, Shajahanpur, Pilibhit, Rampur, Maharajganj, Kheri, Auraiya, Barelli, Hardoi and Barabanki) in 2018, 2017 and 2016. District-wise change in spatial distribution of residue burning events of current year over previous year i.e. 2017 and 2016 for Punjab are shown in Figure 10. In comparison with 2017, the results indicated that Amritsar and south-western districts (Fazilka, Muktsar and Bhatinda) of Punjab showed extremely low reduction in burning events as compared to other districts. Districts such as Fatehgarh Sahib, Rupnagar, Hoshiarpur, Nawashahar and Kapurthala showed significant reduction $(-47 \%$ to $-72 \%)$ in burning events over 2017 . Similarly comparing with 2016, Amritsar and south-western districts (Fazilka, Muktsar and Bhatinda) showed substantial reduction $(-18 \%$ to $-45 \%)$ and other districts, Fatehgarh Sahib, Rupnagar, Hoshiarpur, Nawashahar and Kapurthala also showed a considerable reduction (-60\% to $-87 \%)$. In Haryana (Figure 10), comparing data for 2018 with 2017, major paddy growing districts showed significant reduction (-15\% to $-55 \%)$ in burning events, while it was lowest in districts Hisar and Jhajjhar. Similarly, 2018 with 2016, most of the districts showed substantial reduction (-18\% to $-99 \%)$, whereas, Jind showed extremely low reduction in burning. In Uttar Pradesh (Figure 10), on comparing the 2018 fire event data with that of 2017, 60 districts experienced significant reduction in burning events $(-38 \%$ to $-79 \%)$ except for 15 districts (Hathras, Siddhartnagar, Aligargh, Badaun, Bahraich, Shrawasti, Balrampur, Gorakhpur, Kushinagar, Gazipur, Fatehpur, Barabanki, Allahbad, Mau and Maharajganj. Similarly, on comparing 2018 with 2016, 55 districts showed significant reduction, whereas, Hathras, Siddhartnagar, Badaun, Balrampur, Gorakhpur, Kushinagar, Gazipur, Fatehpur, Allahbad, Mau, Maharajganj, Balia, Banda, Amroha, Kasganj, Etah, Mirzapur, Deoria, Jaunpur, and Kaushambi. 

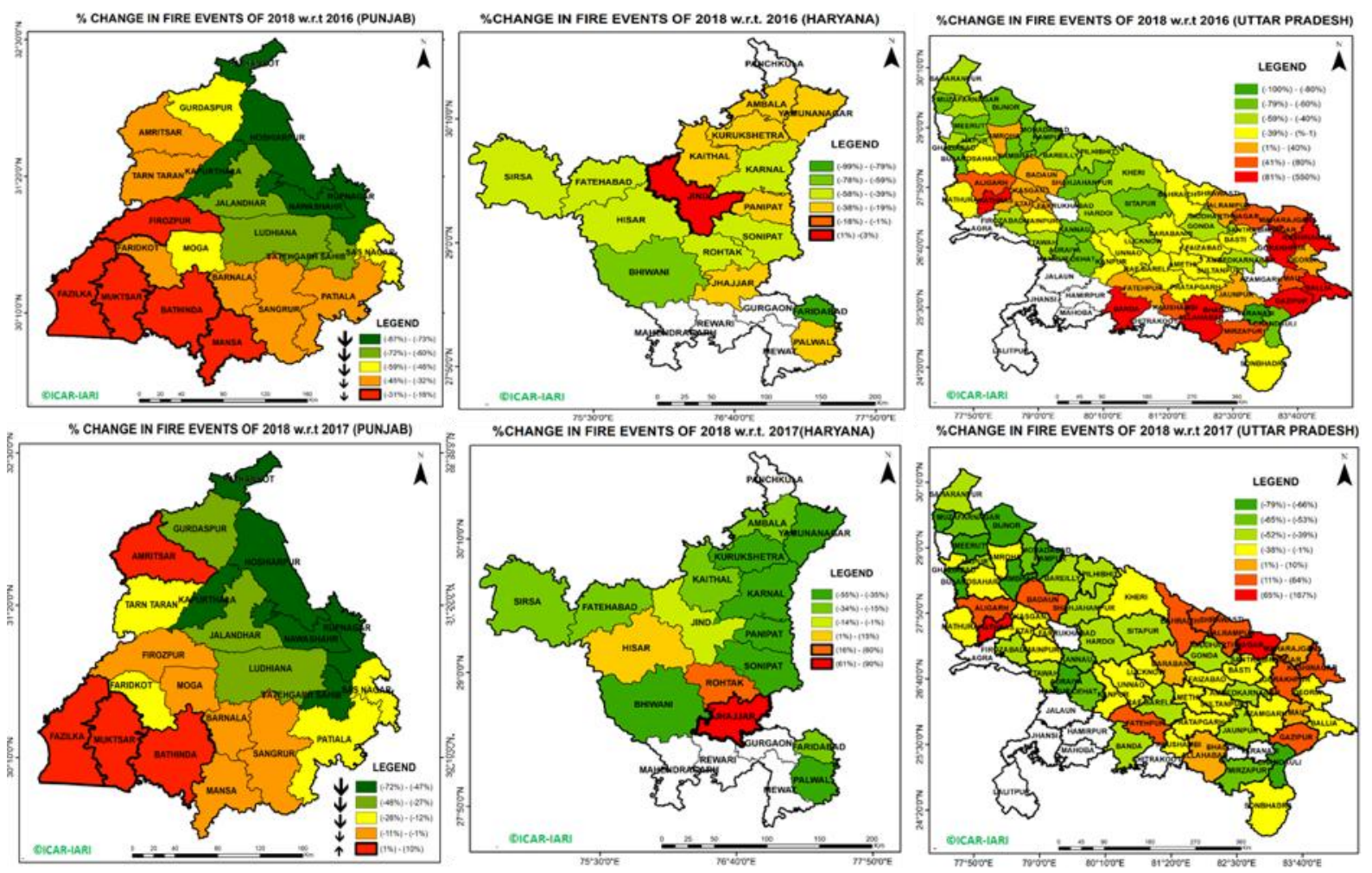

Figure 10. District-wise percentage change in fire count of 2018 with respect to 2017 and 2016 for Punjab, Haryana and UP.

\subsection{Changes in Fire Intensity of Rice Residue Burning in 2018 as Compared to 2017}

The percent change in fire intensity of burning events is provided in Figure 11. In Haryana, about $5.5 \%$ of fire event's intensity in current year changed from very high to low as compared to 2017, signifying increase in partial burning of residue which may lead to lower emission of particulate matter. In UP, in about $4.61 \%$ of burning events, the intensity decreased from very and high to low category in current year as compared to 2017. No change in intensity class of burning events was observed in Punjab in current year as compared to 2017.

\section{CONCLUSION}

The effective implementation of mitigation policies requires continuous near-real-time monitoring of stubble burning. In view of this, satellite remote sensing based monitoring of active fire events due to stubble burning is helpful. Remote Sensing has an advantage of providing multi-temporal, multispectral and repetitive coverage of large areas making the monitoring cost effective and aids in mitigating efforts. The present study on analyzing the spatial-temporal distribution of active fire locations in 2018 (October - November) at district level for Punjab, Haryana and Uttar Pradesh suggests a latent use of satellite datasets for effective monitoring. Descriptive statistical analysis district wise, date and fire intensity wise was carried out and was transmitted daily to the policy makers for mitigation. VIIRS at $(375 \mathrm{~m})$ sensor was able to detect more fires relative to MODIS (1000m) because of its improved fitness to capture small fires using the I-Band. Sudden increase was observed in burning across all the three states during the end week of October and

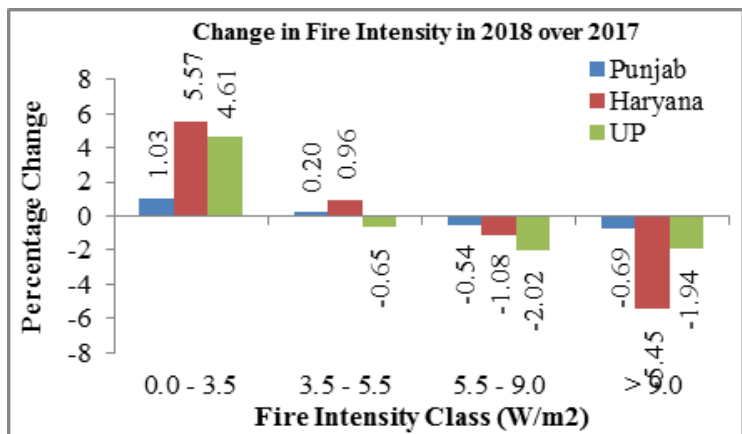

Figure 11. Changes in Fire Intensity of Rice Residue Burning in 2018 as Compared to 2017

beginning period of November. Punjab and Haryana witnessed high intensity fires in major rice growing districts, whereas, in UP high intensity fires were scattered. The data of 2016 and 2017 was also downloaded and computed for comparison. The data indicates that there was $11 \%, 29 \%$, $24 \%$ reduction in Punjab, Haryana and UP respectively as compared to 2017 and $41 \%, 42 \%, 32 \%$ reduction in Punjab, Haryana and UP respectively as compared to 2016. This clearly indicated that 2016 was worst year in crop residue burning and that the reduction of burning in 2018 implies effective implementation of policies by the state and central Government. District wise data analysis of fire events in 2018, 2017 and 2016 indicated that the same districts in Punjab (13), Haryana (5) and UP (10) consistently burn the paddy residue in high quantities. In addition, this data can be used to further estimate the fire intensity based GHG emissions $\left(\mathrm{CO}_{2}, \mathrm{~N}_{2} \mathrm{O}, \mathrm{CH}_{4}, \mathrm{PM} 2.5\right.$ and PM0) and its global warming potential. 


\section{REFERENCES}

Andreae, M.O. and Merlet, P., 2001. Emission of trace gases and aerosols from biomass burning. Global biogeochemical cycles, 15(4), pp.955-966.

Arino, O. and Rosaz, J.M., 1999, June. 1997 and 1998 world ATSR fire atlas using ERS-2 ATSR-2 data. In Proc. Joint Fire Sci. Conf (pp. 177-182). Boise, ID.

Badarinath, K.V.S., Chand, T.K. and Prasad, V.K., 2006. Agriculture crop residue burning in the Indo-Gangetic Plains-a study using IRS-P6 AWiFS satellite data. Current Science, pp.1085-1089.

Badarinath, K.V.S., Kharol, S.K., Sharma, A.R. and Prasad, V.K., 2009. Analysis of aerosol and carbon monoxide characteristics over Arabian Sea during crop residue burning period in the Indo-Gangetic Plains using multi-satellite remote sensing datasets. Journal of Atmospheric and SolarTerrestrial Physics, 71(12), pp.1267-1276.

Crutzen, P.J. and Andreae, M.O., 1990. Biomass burning in the tropics: Impact on atmospheric chemistry and biogeochemical cycles. Science, 250(4988), pp.1669-1678.

Csiszar, I., Schroeder, W., Giglio, L., Ellicott, E., Vadrevu, K.P., Justice, C.O. and Wind, B., 2014. Active fires from the Suomi NPP Visible Infrared Imaging Radiometer Suite: Product status and first evaluation results. Journal of Geophysical Research: Atmospheres, 119(2), pp.803-816.

Elvidge, C.D., Kroehl, H.W., Kihn, E.A., Baugh, K.E., Davis, E.R. and Hao, W.M., 1996. Algorithm for the retrieval of fire pixels from DMSP operational linescan system data. Biomass burning and global change: Remote sensing, modeling and inventory development, and biomass burning in Africa, 1, pp.73-85.

Giglio, L., Descloitres, J., Justice, C.O. and Kaufman, Y.J., 2003. An enhanced contextual fire detection algorithm for MODIS. Remote sensing of environment, 87(2-3), pp.273282.

Giglio, L. and Justice, C.O., 2003. Effect of wavelength selection on characterization of fire size and temperature. International Journal of Remote Sensing, 24(17), pp.3515-3520.

Gupta, R., 2012a. Causes of emissions from agricultural residue burning in north-west India: evaluation of a technology policy response. SANDEE.

Gupta, H.S. and Dadlani, M., 2012b. Crop residues management with conservation agriculture: Potential, constraints and policy needs.

Justice, C.O., Giglio, L., Korontzi, S., Owens, J., Morisette, J.T., Roy, D., Descloitres, J., Alleaume, S., Petitcolin, F. and Kaufman, Y., 2002. The MODIS fire products. Remote Sensing of Environment, 83(1-2), pp.244-262.

Justice, C.O., Kendall, J.D., Dowty, P.R. and Scholes, R.J., 1996. Satellite remote sensing of fires during the SAFARI campaign using NOAA advanced very high resolution radiometer data. Journal of Geophysical Research: Atmospheres, 101(D19), pp.23851-23863.
Kaufman, Y.J., Justice, C.O., Flynn, L.P., Kendall, J.D., Prins, E.M., Giglio, L., Ward, D.E., Menzel, W.P. and Setzer, A.W., 1998. Potential global fire monitoring from EOS-MODIS. Journal of Geophysical Research: Atmospheres, 103(D24), pp.32215-32238.

Ladha, J.K., Fischer, K.S., Hossain, M., Hobbs, P.R. and Hardy, B., 2000. Improving the productivity and sustainability of rice-wheat systems of the Indo-Gangetic Plains: a synthesis of NARS-IRRI partnership research.

Ladha, J.K., Dawe, D., Pathak, H., Padre, A.T., Yadav, R.L., Singh, B., Singh, Y., Singh, Y., Singh, P., Kundu, A.L. and Sakal, R., 2003. How extensive are yield declines in longterm rice-wheat experiments in Asia?. Field Crops Research, 81(2-3), pp.159-180.

Roberts, G. and Wooster, M.J., 2007. New perspectives on African biomass burning dynamics. Eos, Transactions American Geophysical Union, 88(38), pp.369-370.

Sharma, A.R., Kharol, S.K., Badarinath, K.V.S. and Singh, D., 2010. Impact of agriculture crop residue burning on atmospheric aerosol loading--a study over Punjab State, India. Annales Geophysicae (09927689), 28(2).

Schroeder, W., Csiszar, I., Giglio, L. and Schmidt, C.C., 2010. On the use of fire radiative power, area, and temperature estimates to characterize biomass burning via moderate to coarse spatial resolution remote sensing data in the Brazilian Amazon. Journal of Geophysical Research: Atmospheres, 115(D21).

Schroeder, W., Oliva, P., Giglio, L. and Csiszar, I.A., 2014. The New VIIRS $375 \mathrm{~m}$ active fire detection data product: Algorithm description and initial assessment. Remote Sensing of Environment, 143, pp.85-96.

Vadrevu, K.P., Ellicott, E., Badarinath, K.V.S. and Vermote, E., 2011. MODIS derived fire characteristics and aerosol optical depth variations during the agricultural residue burning season, north India. Environmental pollution, 159(6), pp.1560-1569.

Vadrevu, K.P., Ellicott, E., Giglio, L., Badarinath, K.V.S., Vermote, E., Justice, C. and Lau, W.K., 2012. Vegetation fires in the himalayan region-Aerosol load, black carbon emissions and smoke plume heights. Atmospheric environment, 47, pp.241-251.

Vadrevu, K.P., Giglio, L. and Justice, C., 2013. Satellite based analysis of fire-carbon monoxide relationships from forest and agricultural residue burning (20032011). Atmospheric environment, 64, pp.179-191.

Wooster, M.J., Roberts, G., Perry, G.L.W. and Kaufman, Y.J., 2005. Retrieval of biomass combustion rates and totals from fire radiative power observations: FRP derivation and calibration relationships between biomass consumption and fire radiative energy release. Journal of Geophysical Research: Atmospheres, 110(D24). 